\title{
Brief Comment on the Draft Land Administration, Use, Registration and Plan Proclamation, 2007 (EC)
}

DOI http://dx.doi.org/10.4314/mlr.v9i2.6

Daniel Behailu *

The draft 'Land Administration, Use, Registration and Plan Proclamation (2007 EC)' has been in circulation for a while now. One of the prime objectives of the draft law is to address various counterproductive restrictions in the current federal land proclamation. According to its preamble, the draft aspires to expand the rights of land users. The notion of 'expanding rights' presupposes the existence of restrictions and prohibitions in the existing law attributable to narrow conception of rights.

The objective of lifting restrictions is a rights approach. This evokes the question whether the draft law alleviates (or lifts) all restrictions. The draft proclamation has many strong points. It lifts various restrictions of the existing law, especially on the transfer of land rights. However, the restrictions and prohibitions of the federal land proclamation are still embodied in various regional laws thereby necessitating further improvements which are highlighted below.

The title of the proclamation 'Land Administration, Use, Registration and Plan Proclamation, 2007 (EC)' is cumbersome and very long. The current proclamation's title, i.e., 'Land Administration and Use Proclamation' is rather more befitting, and can be used for the draft as well. The supplementary words, i.e., 'registration' and 'plan', are tasks that can be subsumed under the heading 'rural land administration and use'.

With regard to the content of the draft, the issues that need attention include the expansion of land use rights, land registration, pastoral land, land use plan, conflict resolution, sharecropping, and scope of application.

\section{Expansion of Land Use Rights}

The central idea of the draft proclamation can be observed from the preamble. It states that the new law is meant to expand the land use rights of peasants and

\footnotetext{
* Daniel Behailu (LL.B, LL.M, PhD), Asst. Professor of Law at Hawassa University; E-mail: <d.behailu@yahoo.com>
} 
pastoralists. In this regard, the commendable moves of the draft and its shortcomings are the following:

The draft attempts to increase transferability of the land rights by, among others, lifting some limitations of the law on transfer of land rights. ${ }^{1}$ The rights include the right to rent, mortgage, inherit, and donate. But, these rights are still burdened with restrictions: including, the limitation on minimum size to be rented and duration of rent. These rules will be substantiated by future regional laws that will provide the particulars. ${ }^{2}$ The framework legislation suggests for the insertion of limitations in terms of size and duration through regional laws. The challenge lies on how the regions would understand these limitations. Unless these restrictions of the law are entirely lifted, the whole idea of creating land rental market (or increasing transfer of land rights within the constraints of the FDRE constitution) would be futile.

The right to rent one's landholding should not be limited by size and time because the enhancement of credit access and modernizing agriculture and productivity should be encouraged. Such measures are appropriate because they allow and even encourage land consolidation. ${ }^{3}$ The state must rather provide subsidies or other incentives to encourage the consolidation of farms plots toward larger plots - a minimum of one hectare and more. Although the word 'incentives' is mentioned in the draft law, it requires definitions and elaborations, perhaps along with the concept of subsidy.

It is commendable that the draft allows mortgage of use rights ${ }^{4}$. This envisages financial institutions (with due attention to land based loans). However, the draft embodies limitations on rental markets, which should have been encouraged to ensure the development of land markets and credit access. The unlimited rights to rent granted to minors and the elderly is appreciable.

It is to be noted that high value lands (irrigable land, pre-urban land and cash crops' land) have already entered into informal land markets. Legalizing the land market (perhaps rental markets) for these lands is beneficial to the state and the public at large. The modalities of transfer can, for example, be under a lease system or unlimited rental rights.

${ }^{1}$ Article 9-16 of the draft- mentions these improvements (amendments) of the current law; these provisions talks about the rights of rural land holders, especially in terms of use rights, transferring use rights and the right to jointly develop the land with investors.

2 Article 10 of the draft proclamation gives power to regions to limit such rights in terms of size and duration.

3 Article 17 and 18 of the draft proclamation states the right to exchange plots and consolidate farms, and the possibility of getting incentives to do so with purpose to forge better shaped and larger farms.

${ }^{4}$ Article 16 of the draft proclamation mentions about the right to mortgage use rights yet with hosts of limitations as well. 


\section{Land registration}

Registration of land is currently underway. Yet updating land registration ${ }^{5}$ is a major concern in the event of death, transfer, etc. Moreover there is lack of a clear legal regime and institutional framework for the registration of community land and government land. Parcel based $2^{\text {nd }}$ level registration is meant to avoid many problems related to first level registration, among others problems related to concealed holdings and it facilitates updating land information. Even though it is way expensive, Ethiopia can benefit from a selective approach. The first priority can be given to land which is already identified by 'informal land markets' because these lands could be immediately moved to rental markets or lease systems. High value lands such as irrigable land, pre-urban areas, and cash crop areas fall under this category. The following deserve due attention in the draft law:

a) The draft has clearly provided for institutions which could do the updating and registration of community land and government land. However, duplication of offices must be avoided.

b) The draft is still silent on the registration of home and garden of the farmers and how these holdings can be transferred, compensated and valued where necessary.

c) The registration and thereby the certification of land use rights is meaningless unless it promotes rental rights and land markets. This can be done without the need for constitutional amendment, if the limitations in the law are lifted. ${ }^{6}$ Thus, second level registration must be accompanied by free transfer of land rights.

d) In view of the land shortage which is a chronic problem already, rental markets and substantial enhancement of productivity are indispensable. Moreover, there is the need to encourage other economic activities such as agro-based manufacturing. Rental markets can, for example, transfer community lands (especially in the pastoral areas) to youth associations who want to venture to agriculture, while the revenue from rent can be used by the community. This requires detailed directives from the relevant organs.

e) It is also encouraging that community land is kept out of the ambit of distribution and redistribution by the draft law which is one of the weakness (Achilles- heel) in the current land legislations and polices.

${ }^{5}$ Chapter 3 of the draft proclamation regulates registration of rural land, article 1 and 2 of this chapter.

${ }^{6}$ Refer to a book written by the commenter entitled, 'transfer of land rights in Ethiopia: towards a sustainable policy framework', Published in 2015 by Eleven international Publishing- interested person can email the author for the e-copy of the book. 


\section{Pastoral land}

The draft provisions concerning pastoral land ${ }^{7}$ are encouraging and the pastoral society is independently mentioned. Pastoralists deserve to be treated having regard to their custom and way of life. To this end, land registration in pastoral society must aid their way of life. Indigenous knowledge must be protected and any intervention should be preceded by careful scientific study. The certification must also ensure various positive aspects of customary pastoral land use and it should encourage its further use.

The certification must ensure compensation for any encroachment. The compensation payments can be used by the pastoral community which is directly affected based on benefit sharing schemes which must be worked out. Regions can be encouraged to enact separate legislation for postural communities under their jurisdictions. Private holdings under pastoral communities should also be treated as private holdings in non-pastoral communities.

\section{Land use plan}

The draft aspires to promote land use plan which reduces farmlands, especially in the highlands with a concentrated population and wrong agricultural practices. Hence, (i) hill-side farming is expected to discontinue when the land use plan is implemented; (ii) the prohibition of hill-side farming creates more land shortage, and it must be accompanied by vibrant land rental markets which can counterbalance the land shortages through enhanced transferability, consolidation and productivity of prime agricultural land; (iii) other incentives need to be explored and implemented towards creating hill and mountain based businesses, such as tourism, timber (i.e. private and community forests along with regulated harvesting) and forage production.

\section{Conflict Resolution and disputes on land ${ }^{8}$}

Nearly half of the court litigations in Ethiopia involve land related disputes. The draft duly encourages amicable land dispute resolution outside the Rural Land Administration Committee (RLAC) which operates in a court-alike fashion. RLAC and its role need to be carefully spelt out in a manner that would avoid corruption and right violations if it is to be included in the new legal framework. The Woreda court is first instance court, and it is advisable to have land benches at this level, and continuous training should be provided to judges involved in land dispute matters.

\footnotetext{
${ }^{7}$ Chapter 7 of the draft proclamation is dedicated to the rights of pastoral society with respect to land.

${ }^{8}$ Chapter 8 of the draft proclamation regulates the nature of dispute resolution with respect to land.
} 
It is commendable that locus standi is widened in the protection of land rights with regard to women and children. It is also helpful to include free legal aid in the draft law that can be provided by anyone interested (including NGOs and Universities).

\section{Sharecropping ${ }^{9}$}

The draft law ventures to regulate sharecropping. The challenge in this regard can be whether a formal legal regime (that goes beyond providing general principles and standards) can be as effective as traditional systems. Matters of sharecropping can thus be left to the traditional systems and the law can merely afford recognition to the culture as far as it does not conflict with basic tents of the law. Sharecropping is an ancient custom which functions well without even state interventions.

\section{Scope of application}

According to Article 6 of the Draft Proclamation, reference is made to persons '...mainly engaged in agriculture for livelihood'. The word 'mainly' is employed to make reference to those who have rural land use rights. The ambiguity lies in whether it includes low income government employees, petty traders and laborers, etc. who are somehow directly or indirectly involved in agricultural activities. Thus there is the need for clarity and specific reference to the persons without using ambiguous words such as 'mainly.' In other words, there should be specific standards which clearly identify the persons who come under the Draft Proclamation. Otherwise, vague provisions create problems in lieu of the solutions they purport to bring about.

\section{Conclusion}

The draft law is still in circulation (i.e., it is constantly changing) and it is being debated on. It is advisable to invite further discussions on the law and include views from different stakeholders. It is also essential to harmonize the law with other Ethiopian laws and pursuits, particularly in the realms of human rights (economic rights among others), environmental protection, indigenous knowledge protection and sustainable development.

However, such discourse should not prolong the timeline for the enactment of the draft law because it is long overdue. Ethiopia's pursuits of sustainable development and its aspirations to enhance the livelihoods of the rural population call for the enactment of the draft law as soon as possible with all sensible comments addressed, especially comments that expand the scope and transferability of land users rights.

\footnotetext{
${ }^{9}$ See chapter 2 , article 14 of the draft which requires registration of such contracts and more.
} 